\title{
ETHNOPHARMACOLOGY OF RHINOCEROS HORN. I: ANTIPYRETIC EFFECTS OF RHINOCEROS HORN AND OTHER ANIMAL HORNS
}

PAUL PUI-HAY BUT, LAI-CHING LUNG and YAN-KIT TAM

Department of Biology and Chinese Medicinal Material Research Centre, The Chinese University of Hong Kong, Shatin, N.T. (Hong Kong)

(Accepted April 5, 1990)

\section{Summary}

Intraperitoneal administration of an aqueous extract of rhinoceros horn at $5,2.5$ and $1 \mathrm{~g} / \mathrm{ml}$, showed a significant antipyretic effect in rats with hyperthermia induced by subcutaneous injection of terpentine oil. Similar assays with extracts of the horns of saiga antelope, water buffalo and cattle at $5 \mathrm{~g}$ / $\mathrm{ml}$ also caused a significant drop in fever; however, at $1 \mathrm{~g} / \mathrm{ml}$, only saiga antelope horn produced an antipyretic action.

\section{Introduction}

Fossil records show that in the past as many as 30 genera of rhinoceros roamed the earth (Nowak and Paradiso, 1983), but currently only five species exist. Three of them (Dicerorhinus sumatrensis, Rhinoceros anicornis and $R$. sondaicus) are found in Asia, and the other two (Ceratotherium simum and Diceros bicornis) in Africa. In the 17 years between 1970 and 1987, the world's rhinoceros population plummeted from 70,000 to 11,000 , a drop of $85 \%$ (Martin and Vigne, 1987; Sheeline, 1987). This decline is expected to continue unless effective conservation programs can be launched to protect these animals from illegal poaching. The Convention on International Trade in Endangered Species of Wild Fauna and Flora (CITES) has listed all five species of rhinoceros in Appendix I, prohibiting these animals or their products from commercial trading in and among member states joining CITES. Nevertheless, the demand for rhinoceros products, particularly rhinoceros horn, continues in either the open or black markets. This demand for rhinoceros horn comes from two sources: (i) North Yemen where rhinoceros horn is crafted into dagger handles and (ii) Oriental countries where rhinoceros horn is prescribed in traditional medicines. 
Efforts of the World Wild Fund for Nature (WWF) and other conservation agencies have convinced the governments of North Yemen and many Oriental countries to take stricter measures. For example, in North Yemen, which imported almost half the rhinoceros horn on the world market between 1970-1984, a six-point action plan was adopted and has been implemented since 1987 by the government to curtail trading and uses of rhinoceros horn (Martin, 1987). As for many of the Oriental countries and special districts, including mainland China, Taiwan, Hong Kong, Macao, Singapore, Japan, South Korea and Thailand, laws have been enacted to ban export and/ or import of rhinoceros horn (Sheeline, 1987). These legislative or administrative actions are meaningful, but they take little action to modify the beliefs already deeply ingrained in the cultures of traditional medicines.

Practitioners and consumers of herbal medicines using rhinoceros horn swear by it. Herb dealers and herbalists, particularly those in Hong Kong, are very bitter in regard to the ban on rhinoceros horn. They argue that, instead of forbidding them from selling and applying rhinoceros horn to save life, more efforts should be spent to farm and reproduce rhinoceros. Moreover, in dealing with a patient with persistent high fever, the judgement of the dealers and herbalists, albeit necessarily law-abiding, becomes very much a moral one. It is, therefore, most crucial to check the validity of the reputed actions of rhinoceros horn and to seek potent substitutes.

A search of Chinese herbals shows that rhinoceros horn was already listed as a drug of the medium category among the 365 drugs in the Divine Plowman's Herbal (Shennong Bencao Jing, 200 B.C. -200 A.D.). According to that herbal, rhinoceros horn tastes bitter, has cold properties, and is indicated for all intoxications and delirium. Subsequent herbals have added new applications and refined the medicinal value of rhinoceros horn. Current literature (Anonymous, 1977; Hsu et al., 1986) notes that rhinoceros horn is used for dispelling heat (especially heat trapped in blood), cooling blood, relieving convulsion and counteracting toxins, and is employed to treat febrile diseases, influenza, high fever, poisoning, convulsion, epilepsy, restlessness, delirium, macular eruptions, erysipelas, hemoptysis, epistaxis, carbuncle, malignant swelling and abscess. In a review (Wu and $\mathrm{Lu}, 1986)$ on the possible treatment of AIDS with traditional Chinese medicine, rhinoceros horn was suggested helpful in those patients manifesting symptoms of fever and blood heat. Nowhere in Chinese herbals or medical treatises is the use of rhinoceros horn for promoting virility or aphrodisia mentioned, a fact confirmed by Martin (1983). However, this rumor continues to be perpetuated even in major Western medical journals (Gray, 1985; Milstone, 1987). As for oral administration of rhinoceros horn in traditional Chinese medicine, the horn is always filed into fine powder or ground into an emulsion along the inside wall of a clay or porcelain bowl with a small amount of water. The powder or emulsion, raw, is usually swallowed with water or a herbal decoction. The powder is also used in making pills or decoctions in combination with herbal materials (Anonymous, 1977; But et al., 1988). 
Since rhinoceros horn is most often used in hyperthermia, our attention goes first to that area. Several studies have been published on the antipyretic effects of rhinoceros horn; most of them reported negative results. For example, Yuan could not demonstrate any antipyretic effect through oral administration of rhinoceros horn in rabbits with hyperthermia induced by cerebral administration of epinephrine (Yuan, 1987). Huang et al. (1959) induced hyperthermia in rabbits with $E$. coli i.p. and then administered powder of Asian or African rhinoceros horn suspended in acacia at $0.12-0.9$ and $0.4-3.0 \mathrm{~g} / \mathrm{kg}$ p.o., respectively. Comparison of the rectal temperature of the rabbits $1-6 \mathrm{~h}$ after treatment again showed that the two types of rhinoceros horn had no antipyretic effect. Another study on rhinoceros horn, undertaken by Hoffmann-La Roche at the request of the WWF and International Union for Conservation of Nature and Natural Resources (IUCN), also reported no antipyretic properties (D.S. Melville, personal communication). However, intravenous administration of rhinoceros horn extracts was reported successful in relieving fever in rabbits induced by $E$. coli i.v. (Ogata et al., 1960). The contradictory results could be due to differences in routes of administration, types of preparation and dosage levels. Moreover, our experience shows that the model of hyperthermia induced by $E$. coli may not be the best bioassay system for the assessment of the antipyretic effect of rhinoceros horn since this method involves a bacterial toxin and also the duration of hyperthermia induced is rather short. To evaluate the reputed antipyretic effect of rhinoceros horn, it may be better to try another pyrogen such as one that causes inflammation and a longer duration of hyperthermia and to study higher dosage levels.

In this paper we report our results on the antipyretic effects of rhinoceros horn and also compare the actions of horns from saiga antelope (Saiga tatarica), water buffalo (Bubalus bubalis) and cattle (Bos taurus domesticus) under the same experimental conditions.

\section{Materials and Methods}

Horns and preparation of extract

Rhinoceros horn scraps confiscated by customs officials and identified by the Museum of Chinese Medicines at our University as from African black rhinoceros (Diceros bicornis) were made available to this study from the Agriculture and Fisheries Department of the Hong Kong Government. Saiga antelope horn was obtained from commercial sources. Horns of water buffalo and cattle were collected from butchers or meat markets. The bony core, if present, was discarded. These horns were filed into fine powder. An aqueous extract was prepared by boiling the horn powder in hot water $(40 \mathrm{ml} / \mathrm{g})$ for three hours twice and then pooling the supernatants and concentrating to the desired concentrations.

\section{Experimental animals and procedures}

Male Wister albino rats, $200-250 \mathrm{~g}$, each in a cage, were kept in an air- 
conditioned observation room. Rectal temperature of these animals was monitored by a Norelco digital thermometer. In measuring rectal temperature, the experimenter held the tail of a rat loosely, allowing the rat to maintain a normal posture and even sniff around on a bench. Each rat was trained to adapt to the thermometer before experimentation. A single experimenter handled the rats throughout each set of experiments to avoid interpersonal differences in handling the animals.

Terpentine oil was chosen as the pyrogen and was applied at $0.4 \mathrm{ml} / \mathrm{kg} \mathrm{s.c.}$ Rectal temperatures would normally reach $39^{\circ} \mathrm{C}$ or above around the 9 th hour after terpentine oil injection. For each set of experiments, only rats with a rectal temperature above $39^{\circ} \mathrm{C}$ were chosen, but the range of variation of rectal temperature among the rats was kept within $1^{\circ} \mathrm{C}$. Each rat in an experimental group received an aqueous extract of horn at $1 \mathrm{ml}$ i.p. Rats in the control group received an equal amount of saline via the same route of administration. Change in rectal temperature of the rats after treatment was monitored at intervals of $30 \mathrm{~min}$. Three or four hours after the first treatment, another injection of horn extract or saline would be given to the

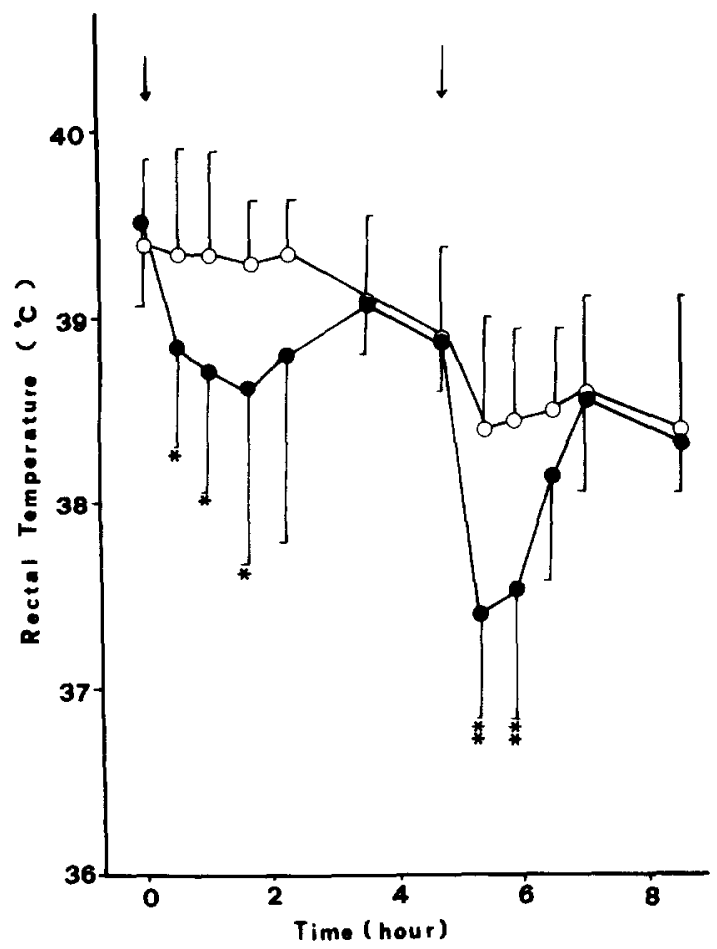

Fig. 1. Antipyretic effect of rhinoceros horn extract at $5 \mathrm{~g} / \mathrm{ml}$ i.p. in male rats $(N=10)$. $O$, control; $\bullet$, rhinoceros horn; ${ }^{*} P<0.05 ;{ }^{* *} P<0.01$. Arrows indicate the first and second administration of horn extract or saline. 
rats in the experimental or control groups, respectively. Monitoring of rectal temperature continued for another three hours at intervals of $30 \mathrm{~min}$.

The experiments were divided into two groups. The first group attempted to determine if aqueous extracts of rhinoceros horn at 5, 2.5, 1 and $0.5 \mathrm{~g} / \mathrm{ml}$ had any antipyretic effect. The second group of experiments attempted to document whether the horns of saiga antelope, water buffalo and cattle at 5 and $1 \mathrm{~g} / \mathrm{ml}$ had similar antipyretic activities. Each set of experiments was repeated twice. Student's $t$-test was used in statistical analysis.

\section{Results}

\section{Rhinoceros horn}

At $5 \mathrm{~g} / \mathrm{ml}$ i.p., the aqueous extract of rhinoceros horn consistently demonstrated a significant antipyretic effect 30 min after treatment (Fig. 1). This antipyretic action lasted for about $1.5 \mathrm{~h}$, after which rectal temperature of these rats gradually returned to hyperthermic conditions as in the control group given only saline. The second dose of the aqueous extract was followed by another significant drop in rectal temperature. Comparison of the

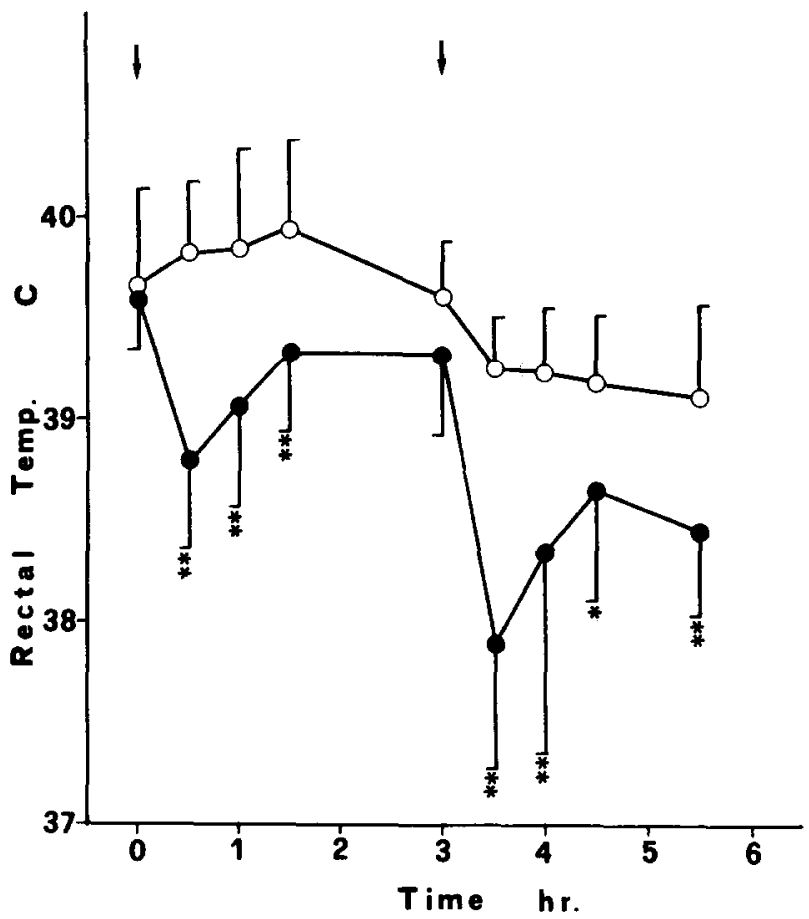

Fig. 2. Antipyretic effect of rhinoceros horn extract at $2.5 \mathrm{~g} / \mathrm{ml}$ i.p. in male rats $(N=10)$. control; $\bullet$, rhinoceros horn; ${ }^{*} P<0.05$; $* P<0.01$. Arrows indicate the first and second administration of horn extract or saline. 
responses of the first and second injections clearly showed that the second injection caused a larger antipyretic response.

Qualitatively similar antipyretic activities were noted in experimental groups given 1 or $2.5 \mathrm{~g} / \mathrm{ml}$ of the aqueous extract of rhinoceros horn (Figs. 2,3). Neverthelcss, responses of rats treated with $1 \mathrm{~g} / \mathrm{ml}$ of the horn extract tended to fluctuate more after the first injection (Fig. 4). Repeated assays at $0.5 \mathrm{~g} / \mathrm{ml}$ of the horn extract, however, did not demonstrate any significant antipyretic activities (Fig. 4).

Horns of saiga antelope, water buffalo and cattle

At $5 \mathrm{~g} / \mathrm{ml}$ i.p., the aqueous extracts of the horns of saiga antelope, water buffalo and cattle also demonstrated significant antipyretic action after both the first and second injections (Figs. 5,6). Another preliminary observation seemed to indicate that, at this high dose level, saiga antelope horn tended to have stronger antipyretic effects than rhinoceros horn. At $1 \mathrm{~g} / \mathrm{ml}$ the aqueous extracts of saiga antelope horn showed some significant antipyretic activities, whereas horns of water buffalo and cattle did not show any action (Fig. 7).

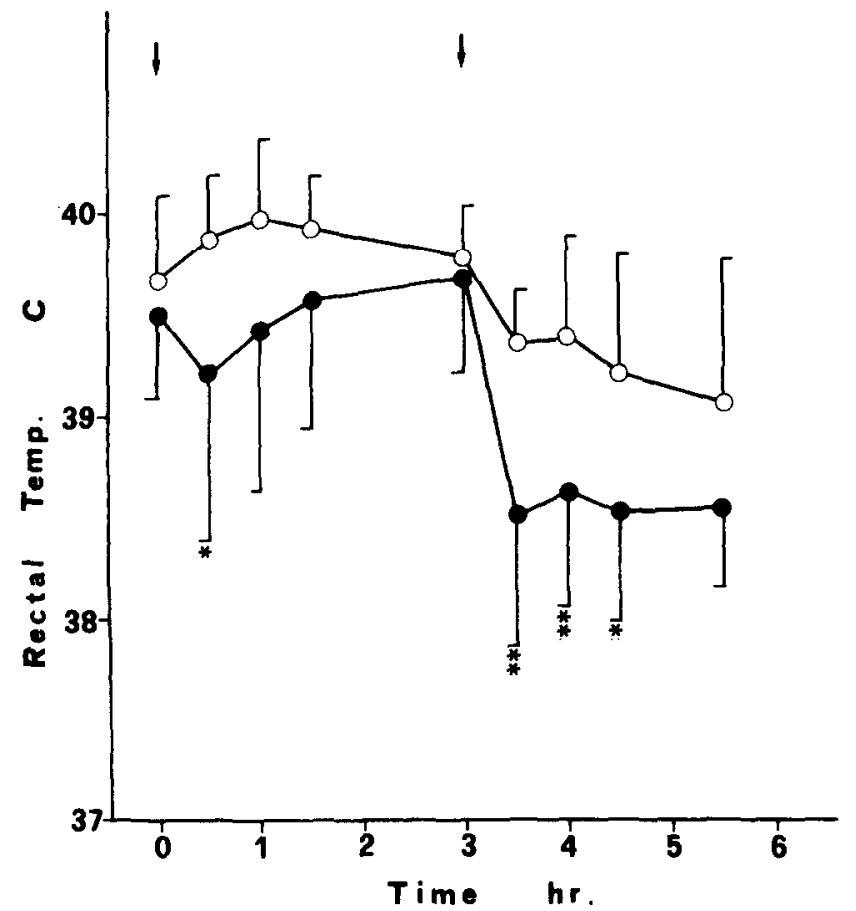

Fig. 3. Antipyretic effect of rhinoceros horn extract at $1 \mathrm{~g} / \mathrm{ml}$ i.p. in male rats $(N=10)$. $O$, control; - rhinoceros horn; $* P<0.05 ; * * P<0.01$. Arrows indicate the first and second administration of horn extract or saline. 


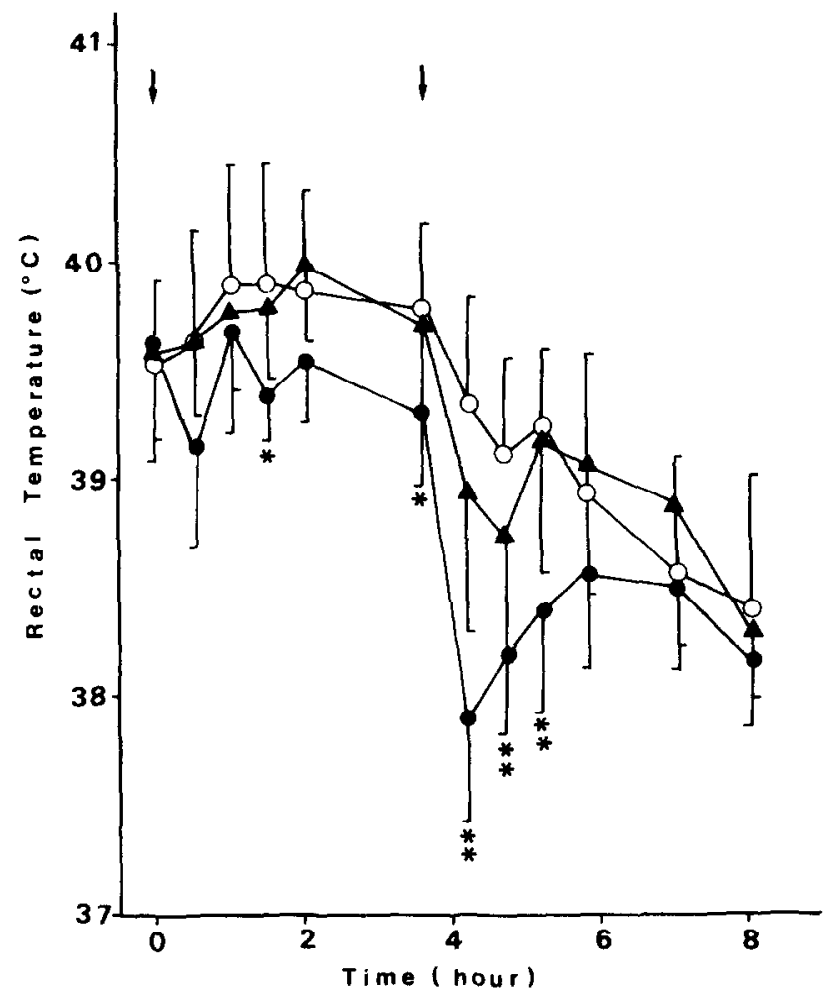

Fig. 4. Antipyretic effect of rhinoceros horn extract i.p. in male rats $(N=7)$. 0 , control; $\bullet$, rhinoceros horn $1 \mathrm{~g} / \mathrm{ml} ; A$, rhinoceros horn $0.5 \mathrm{~g} / \mathrm{ml} ; * P<0.05 ;{ }^{* *} P<0.01$. Arrows indicate the first and second administration of horn extract or saline.

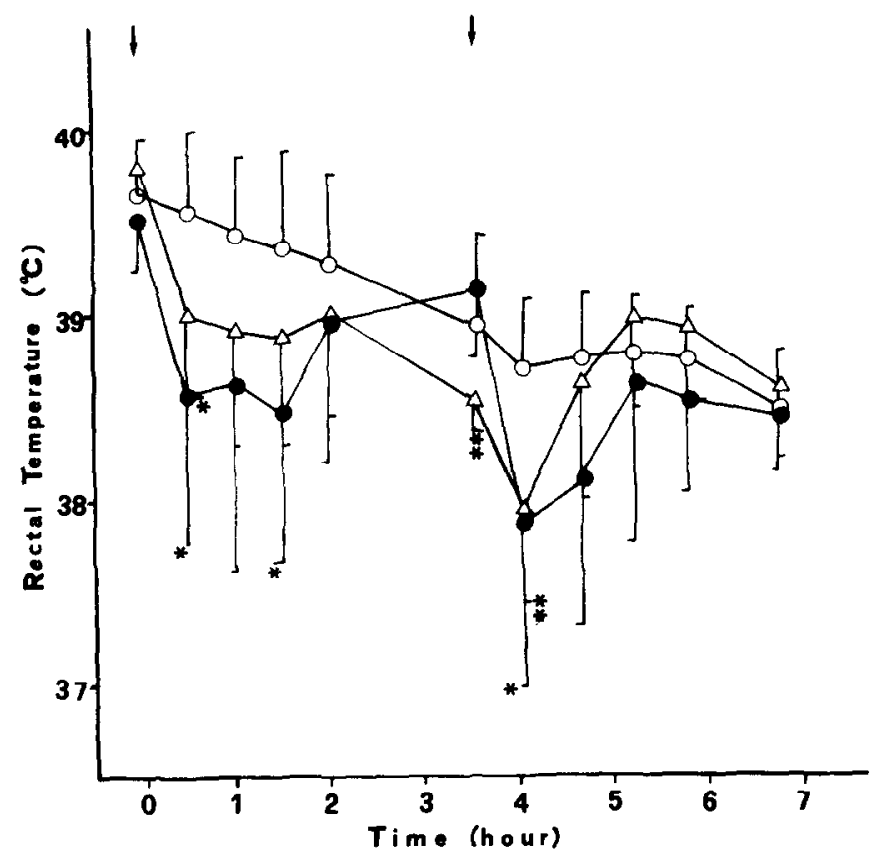

Fig. 5. Antipyretic effect of rhinoceros horn and cattle horn extracts at $5 \mathrm{~g} / \mathrm{ml}$ i.p. in male rats $(N=8)$. $O$, control; $\bullet$, rhinoceros horn; $\Delta$, cattle horn; ${ }^{*} P<0.05 ;{ }^{* *} P<0.01$. Arrows indicate the first and second administration of horn extract or saline. 


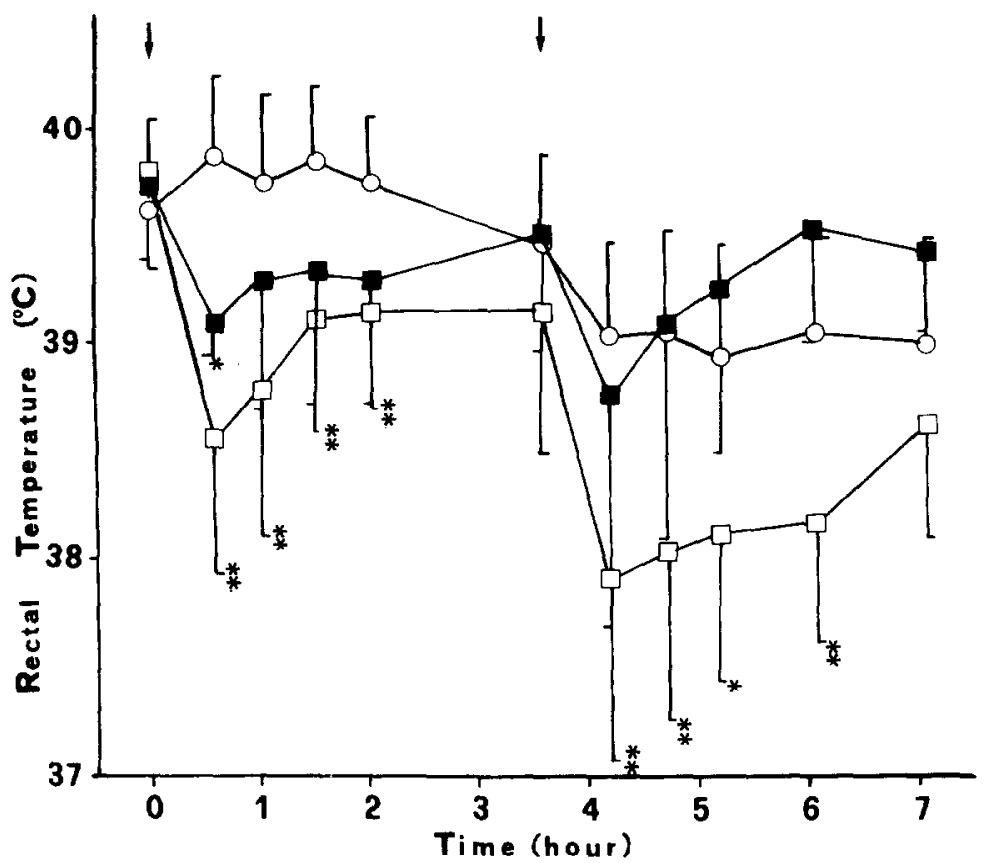

Fig. 6. Antipyretic effect of water buffalo horn and saiga antelope horn extracts at $5 \mathrm{~g} / \mathrm{ml}$ i.p. in male rats $\left(N=8\right.$ ). $O$, control; $\square$, water buffalo horn; $\square$, saiga antelope horn; ${ }^{*} P<0.05 ; * * P<$ 0.01 . Arrows indicate the first and second administration of horn extract or saline.

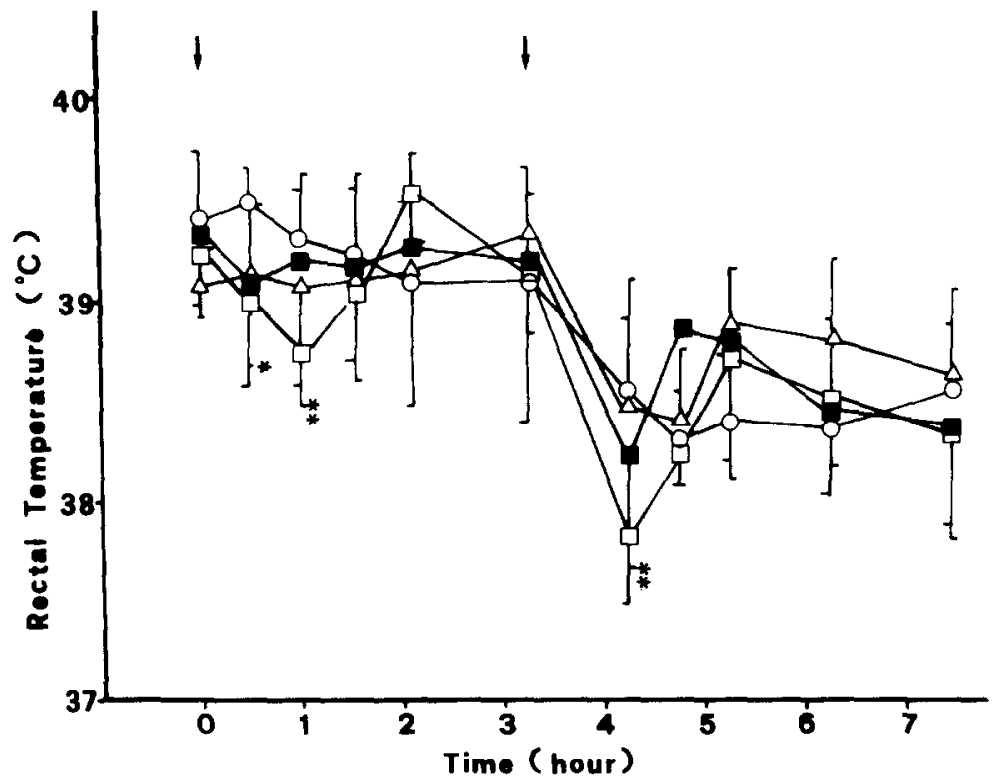

Fig. 7. Antipyretic effect of the horn extracts of water buffalo, saiga antelope and cattle at $1 \mathrm{~g} / \mathrm{ml}$ i.p. in male rats $(N=5)$. $O$, control; $\square$, water buffalo horn; [] , saiga antelope horn; $\Delta$, cattle horn; ${ }^{*} P<0.05 ;{ }^{*}{ }_{P}<0.01$. Arrows indicate the first and second administration of horn extract or saline. 


\section{Discussion}

Rhinoceros horn has been used in Chinese medicine for over 2,000 years and, apparently, produces a satisfactory response in humans. Recent reports on clinical studies claimed that compound prescriptions containing rhinoceros horn were effective in treating the majority of cases of hyperthermia (Anonymous, 1975). Previous pharmacological studies on the antipyretic properties of rhinoceros horn, however, produced contradictory conclusions (Huang et al., 1959; Ogata et al. 1960; Yuan, 1987). To overcome the problem of dosage level and absorption, we chose to start with an extremely high dose of rhinoceros horn given by intraperitoneal administration; this high dose, $5 \mathrm{~g} / \mathrm{ml} /$ rat, would be equal to over 100 -fold of the normal human oral dose. Our rationale was that, if no activity could be demonstrated at this level, we could definitely cast doubt on the reputed antipyretic value of rhinoceros horn. We also suspected that a second injection might be informative. In our assays at $5 \mathrm{~g} / \mathrm{ml}$, rectal temperature was consistently lowered after both first and second injections in rats. Reduction of the dosage level to 2.5 and 1 $\mathrm{g} / \mathrm{ml}$ continued to demonstrate significant antipyretic action. However, at 0.5 $\mathrm{g} / \mathrm{ml}$ no antipyretic effect could be shown for the rhinoceros horn extract. Apparently, based on the results of this study, rhinoceros horn can reduce fever, but only at rather high dosage levels when prescribed as a single drug.

A few clinical studies have suggested that antipyretic action can also be found in the horns of saiga antelope (Ding, 1977; Li and Wang, 1979), water buffalo (Anonymous, 1975) and cattle ( $\mathrm{Li}, 1964)$. In the present study, under the same experimental conditions, horn extracts of saiga antelope, water buffalo and cattle also demonstrated significant antipyretic action at the high dosage level of $5 \mathrm{~g} / \mathrm{ml}$. However, except for saiga antelope horn, actions of the other two animal horns at the low dosage level of $1 \mathrm{~g} / \mathrm{ml}$ were much weakened. This observation appears to support the claims of some herbalists that when using water buffalo horn as a substitute the dosage level must be increased by 10 -fold.

Chemically, rhinoceros horn contains keratin, amino acids, guanidine derivatives, sterols, amine (ethanolamine), acidic peptide and sugar- and phosphorus-containing substances. (Inagaki and Oida, 1970; Yuan, 1987). The profile of water-soluble amino acids was found to be very similar to those of saiga antelope (Shigematsu et al., 1982) and water buffalo (Anonymous, 1975), but quite different from that of cattle (Inagaki and Oida, 1970; Lee and Kim, 1974). Rhinoceros horn also contains many trace and metallic elements, including a high amount of calcium (Anonymous, 1975; Zhang et al., 1984). It would be most interesting to identify which components actually contribute to the antipyretic action. The mechanism of action of rhinoceros horn, however, is considered to be complicated (Ye and He, 1962).

Before a final verdict is given on the antipyretic property of rhinoceros horn, it would be most relevant to review briefly the role of rhinoceros horn in the conceptual context of Chinese medicine. Chinese medicine is an inte- 
grated body of empirical knowledge and experience developed in a similar way to that of a person trying to detect the physical changes of a sealed black box and to devise means to restore it to a 'normal' state (But and Kong, 1984). Based on systematic observations of the physical and biological changes in humans, including temperature, humidity, color, odor, pulse, excretions and expressed feelings, as well as systematic correlation and classification of external changes, particularly weather, environment, food intake, and physical and psychological impacts, Chinese medicine was built on a matrix of assumed causes and observed changes. A very fundamental approach in Chinese medicine in analysing the syndromes of an ailment is to differentiate them according to the 'eight cardinals': yin, yang, outside, inside, empty, full, cold and hot. The eight cardinals are actually four pairs of mutually opposing, but interdependent and interchanging parameters, which are intended to help specify or circumscribe the causes, sites, extent, nature and state of development of a disease, as well as the body's resistance to the disease. Under the cardinals outside and inside, the site of a disease is often further subdivided systemically into four domains or layers (more specifically into various vital organs and channels); the four domains are, successively from the outside, wei (defence), $q i$ (air), ying (maintenance) and $x u e$ (blood). The deeper the site, the more serious a disease. Moreover, in Chinese medicine, the term 'fever' covers not only a rise in body temperature but also a patient's subjective feeling of heat within his body (Otsuka et al., 1982). Diagnosis of fever, however, does not rely solely on body temperature, but also on other symptoms. Hence, a patient having body temperature above $40^{\circ} \mathrm{C}$ but pale face, dull pulse, watery stool and clear urine is regarded as having a cold disease, not a hot disease. Moreover, fevers are more finely classified into many types, according to the combination of the parameters diagnosed. Fevers towards the outside or at $w e i$ are to be treated with sweating or sudorific agents, whereas fevers deep in ying or xue would require fire-purging (refreshing) drugs. On the other hand, herbal materials are noted to have such properties as four essences, five flavors and four directions of action. The four essences are cold, hot, cool and warm. A cold drug alleviates yang diseases, inflammation or hyperemia, and various fevers (Hsu and Peacher, 1982). Once a disease is properly diagnosed or circumscribed, treatment is to apply herbal materials to reverse the imbalance back towards the equilibrium and to expel the disease from within to without. Accordingly, rhinoceros horn, classified as a cold drug, is indicated for hot diseases. However, it is applied only when heat is trapped deep in the body in the areas of ying and xue, to help clean and detoxify the blood. Obviously, the conceptual function of rhinoceros horn in Chinese medicine is more far-reaching than just subsiding fever. Furthermore, it should be noted that, although both rhinoceros horn and saiga antelope horn are used in cases of heat trapped in ying and wei, the former is regarded as superior in cooling blood and counteracting toxins, whereas the latter horn is better in cooling liver and quenching wind (Jiao, 1977). Although the present study showed that both rhinoceros horn and saiga antelope horn have potential antipyretic 
properties, further study may be necessary to differentiate between the actions of the two horns.

Assuming the assay model employed in this study truly reflects and confirms the antipyretic action of rhinoceros horn in purging heat as described in the conceptual framework of Chinese medicine, the horns of saiga antelope, water buffalo and cattle could be used as an alternative, although their dosage levels may have to be increased.

\section{Acknowledgments}

Partial support was received with gratitude from the World Wild Fund for Nature Hong Kong, Agriculture and Fisheries Department, Tung Fong Hung Medicine Company Ltd., and Chinese Medicinal Material Research Centre and Chung Chi College of The Chinese University of Hong Kong. Assistance from S.M. Fong, C.C. Wai and D.S. Melville is also deeply appreciated.

\section{References}

Anonymous (1975) Clinical observation on 3871 cases treated with water buffalo horn and preliminary report on chemical analysis and pharmacology of the horn. Zhongcaoyao Tongxun 6, 107 -109 .

Anonymous (1977) Encyclopedia of Chinese Materia Medica (Zhongyao Dacidian). Shanghai Science and Technology Press, Shanghai.

But, P.P.H. and Kong, Y.C. (1984) Chinese medicinal plants and their uses. Hamdard 27 (3), $47-$ 52.

But, P.P.H., Lung, L.C. and Tam, Y.K. (1988) Profiles of Chinese medicines 4. Rhinoceros horn. Abstracts of Chinese Medicines 2, $351-360$.

Ding, R. (1977) Injections of saiga antelope horn prepared by hydrolysis (with clinical data). Zhongcaoyao Tongxun 8, 17-19.

Gray, C. (1985) Hong Kong: highrise hospitals and powdered rhino horn. Canadian Medical Association Journal 132, 834-836, 838-839.

Hsu, H.Y. and Peacher, W.G. (1982) Chinese Herb Medicine and Therapy (Revised edition). Oriental Healing Arts Institute of U.S.A., Los Angeles.

Hsu, H.Y., Chen, Y.P., Shen, S.J., Hsu, C.S., Chen, C.C. and Chang, H.C. (1986) Oriental Materia Medica, A Concise Guide. Oriental Healing Arts Institute, Long Beach.

Huang, H.Q., Xu, J.L. and He, J.L. (1959) Antipyretic effect.s of Asian and A frican rhinoceros horns. Wuhan Yiyao Weisheng /Wuhan Medicine and Hygiene/ 2, 340-343.

Inagaki, I. and Oida, N. (1970) On the constituents of rhinoceros horn (I). Nagoya Shiritsu Daigaku Yakugakubu Kenkyu Nempo 18, 57-66.

Jiao, S.D. (1977) Ten Lectures on Insight in Drug Application. People's Health Publishing House, Beijing.

Lee, S.K. and Kim, Y.E. (1974) Compositions of hard tissue proteins extracted from bovine horn, water buffalo horn, and rhinoceros horn. Hanguk Saenghwa Hakhoe Chi 7, 125-142.

Li, T.P. (1964) Substituting rhinoceros horn with cattle horn in treating febrile diseases. Guangdong Medical Journal 1964 (5), 31.

Li, Y.G. and Wang, C. (1979) Preliminary studies on the horns and horn injections of Suigu tuturica, Carpa nisaus and Pracapra guttorsa. Zhongcaoyao Tongxun 10, 204-209.

Martin, E.B. (1983) Rhino Exploitation, the Trade in Rhino Products in India, Indonesia, Malaysia, Malaysia, Burma, Japan and South Korea. World Wildlife Fund Hong Kong, Hong Kong. 
Martin, E.B. (1987) Clamp-down on rhino-horn trade in North Yemen. Species 9, 21-23.

Martin, E.B. and Vigne, L. (1987) Recent developments in the rhino horn trade. Traffic Bulletin $9,49-53$.

Milstone, L.M. (1987) Skin potions. Archives of Dermatology 123, 1087-1088.

Nowak, R.M. and Paradiso, J.L. (1983) Walker's Mammals of the World. Johns Hopkins University Press, Baltimore, MD.

Ogata, J., Maeda, T. and Ide, T. (1960) Studies on the water-extract of saikku (horn of Rhinoceros sp.). Bulletin of Yamaguchi Medical School 9, 1940-1943.

Otsuka, K., Yakazu, D. and Shimizu, T. (1984) In: II.Y. IIsu (Eds.), Natural Healing with Chinese Herbs. Oriental Healing Arts Institute, Los Angeles.

Sheeline, L. (1987) Is there a future in the wild for rhinos? TRAFFIC (U.S.A.) 7(4), 1-6, 24.

Shigematsu, N., Kouno, I., Kawano, N., Shintake, S. and Hori, T. (1982) On the water-soluble amino acids in the horns of Saiga tatarica and Rhinoceros spp. Shoyakugaku Zasshi 36, 104105.

Wu, B.P. and Lu, S.K. (1986) Discussions on the possible treatment of AIDS with traditional Chinese medicine. Beijing Journal of Traditional Chinese Medicine 1, 14-16.

Ye, D.J. and He, Y. (1962) Pharmacological comparison of rhinoceros horn, buffalo horn, sheep horn and swine nail. Jiangsu Journal of Traditional Chinese Medicine (1962) 11, 1-4.

Yu, L.W. (1983) Diagnosis and treatment of fever in Chinese medicine. Jizhenyikan (Basic Medical Journal 1, 2-4.

Yuan, W. (1987) Rhinoceros horn. In: H.M. Chang and P.P.H. But (Eds.), Pharmacology and Applications of Chinese Materia Medica, Vol. 2. World Scienfitic Publishing Co., Singapore, $1178-1179$.

Zhang, Y.H., Liu, Y.G., Diao, G.P. and Xiao, L. (1984) Neutron activation analysis of trace elements in horn of rhinoceros and buffalo. Hejishu 2, 45-46. 